\title{
Application of Biotechnology in Coconut (Cocos nucifera L.): Sri Lanka
}

\author{
YMAM Wijerathna* \\ Postgraduate Institute of Agriculture (PGIA), University of Peradeniya, Sri Lanka
}

Key words: Cocos nucifera, Tissue culture, Molecular marker, Diversity

\begin{abstract}
With the growing of world population and industrialization there is rising demand for coconut-based health and beauty products. The producers might not be able to keep up this demand with the law production of coconut due to the land area under cultivation has declined from around 444,000 hectares to about 394, 840 hectares between 2000 and 2012 and the aging trees in coconut trees. So there is an urgent need for shifting to investigate how the use of recently developed biotechnological techniques can benefit the coconut industry. Here the describes recent utilization of (a) molecular markers, diversity and genetic improvements, (b) molecular detection and diagnosis of diseases; and (c) in vitro propagation in Sri Lanka and the future potential of biotechnology on the coconut industry.
\end{abstract}

\section{Introduction}

Coconut (Cocos nucifera L.) is a versatile crop that is known to as "Kalpavruksha" (Tree of Heaven), "Natures Super Market", "Tree of Abundance" and "Tree of Life". The coconut industry plays a major role in sustaining the national economy and food security of the people. Furthermore, $80 \mathrm{~g}$ of coconut meat provide 283 calorie ( $14 \%$ of daily value) intake of an average person and coconut is the major source of $41 \%$ of edible oils and fats in the daily diet (Anon. 2014).

The main coconut based export products are desiccated coconut (DC), copra, coconut oil, coconut milk powder and coconut cream. Some other husk and shell based products are coir fiber, value added coir based products, fiber briquettes, Geotextiles, shell charcoal, activated carbon and shell powder. Coir is the fiber obtained from the coconut husk and it is used to make matting, rugs, ropes and fiberboard etc. A by-product of its manufacturing process is coir dust that is used as a soil conditioner in the horticulture industry. India and Sri Lanka are the only

*E-mail: <akila.yapa@mail.huji.ac.il>. 
two significant coir producers in the world. The trunk is used in house and building construction and furniture making. The leaves after plaiting are used to thatch houses. The sap obtained from tapping the inflorescence is rich in sugar and is converted into jaggery, sugar, vinegar and sweet or fermented toddy (Wijerathna 2012).

Countries in the Asia and Pacific region are leading coconut producers in the world and most of coconut cultivated lands are concentrated within this region. Philippines and Indonesia possess the biggest land extent (Table 1) and Indonesia, India and Philippines are the highest producer (Table 1) of coconut among Asia and Pacific Coconut Community Countries (APCC). Productivity of coconut lands in some countries showed significant difference from their net coconut production such as in Philippines and Indonesia. In Philippines the productivity of coconut lands are low (Table 1) compared to other coconut producing countries but it is the world leader in coconut production (Table 1) due to its' high land extent.

Table 1. Coconut area (1000 ha) and coconut production in whole nuts (1000 nuts) by APCC member countries in 2012.

\begin{tabular}{lll}
\hline Country whole nuts & Area ('000 ha) & ('000 nuts) \\
\hline Federated Sates of Micronesia & 17 & 40,000 \\
Fiji & 60 & 165,000 \\
India & 1,890 & $16,943,000$ \\
Indonesia & 3,810 & $15,429,000$ \\
Kiribati & 29 & 131,300 \\
Malaysia & 109 & 577,000 \\
Marshall Islands & 8 & 34,000 \\
Papua New Guinea & 221 & $1,101,000$ \\
Philippines & 3,562 & $15,248,000$ \\
Samoa & 99 & 20,000 \\
Solomon Islands & 38 & 100,000 \\
Sri Lanka & 395 & $1,833,000$ \\
Thailand & 216 & 845,000 \\
Tonga & 8 & 44,400 \\
Vanuatu & 96 & 307,700 \\
\hline
\end{tabular}

Source: Coconut Statistical Year Book 2013, APCC.

Over a period of three decades there is considerable decrease in coconut area. The decline in productivity and coconut area particularly is due to the large number of small holdings, old unproductive palms, inadequate water 
management and input management and blocking out the coconut lands for the purpose of construction (Wijerathna 2012).

By implementing the latest biotechnological techniques in plant molecular genetics, molecular breeding and laboratory techniques there is a potential of development of new useful coconut varieties with the available diverse germplasm to overcome such problems reducing time needed for developing a new variety.

The history of coconut in Sri Lanka is driven to the ancient time as 300 B.C. Coconut palm is not native to Sri Lanka and it is believed that coconut palm introduced to Sri Lanka by India (Menon and Pandalai 1958). Historical records revealed that the growing of coconut palms in home gardens has been done in the Rajarata (Anuradhapura Kingdom) since the second century BC, and has developed into a plantation crop early in the 20th century. According to "The Mahawansa", coconut palms were growing along the Southern coastal belt in the King Dutugamunu era as early as 161 B.C. Marco Polo who is best known for his overland travels in $1300 \mathrm{AD}$, reported that inhabitants of some parts of Ceylon were even at that time, drinking toddy obtained from coconut palms.

In Sri Lanka the land area under cultivation has declined from around 444,000 hectares to about 394, 840 hectares between 2000 and 2012 (Central Bank 2014). Coconut industry contributes about $1.1 \%$ to the gross domestic products (GDP) and 3.3 per cent to the total export earnings (Table 2). Earnings from coconut product exports increased by 60.3 per cent to US dollars 23 million, due to improved performance in both kernel and non-kernel coconut products in terms of both price and volume and Sri Lanka is the largest coconut consuming country where $70-80 \%$ of coconut is utilized for domestic consumption (Central Bank 2014).

Sri Lanka has three "indigenous" varieties of coconut. There are three types of coconut varieties in Sri Lanka known as Typica, Nana and Aurantiaca (Liyanage 1958). Typica palms are generally tall, grow to about 60 feet in height, produce a bole at the base of the trunk, long leaves, and come into bearing in about 6 - 8 years from planting. These palms are generally resistant to soil water deficit. Major cultivar forms of Typica are Navasi, Gon Thembili, Ran thembili, Porapol, Bodiri, Kamandala, and Dikiri pol. Nana palms have a shorter stature growing to about 30 feet in height, does not produce a bole, shorter leaves, come into bearing about 3 - 4 years from planting and susceptible to soil water deficit. Major cultivar forms of Nana are Pumilla-green, Eburnea-yellow and Regia-red. The variety Aurantiaca palms are generally grows to about 40 feet in height, shorter leaves, comes into bearing in about 5 - 6 years, self-pollinating and susceptible to 
water deficits. And also it is susceptible to insect pest attacks. Major cultivar forms are Thembili, Navasi Thembili and Rath Ran Thembili.

The cultivar Thembili is the commercially grown cultivars of coconut in Sri Lanka. Typica is the most extensively grown cultivar of coconut. Therefore, we have a very narrow genetic base. If this commercially grown cultivars become susceptible to any damaging pest or disease can have serious repercussions, even total devastation of the coconut industry (Wijerathna 2012).

Table 2. Economic and social statistics of Sri Lanka 2013, Central Bank of Sri Lanka.

\begin{tabular}{lcccc}
\hline Year & $\begin{array}{c}\text { Coconut, Mn. } \\
\text { nuts }\end{array}$ & $\begin{array}{c}\text { Domestic Consumption } \\
\text { Mn. nuts }\end{array}$ & $\begin{array}{c}\text { Exports, Rs. } \\
\text { billion (a) }\end{array}$ & $\%$, GDP \\
\hline 2004 & 2,591 & 1,853 & 11.5 & 2.0 \\
2005 & 2,515 & 1,872 & 11.4 & 2.1 \\
2006 & 2,785 & 1,901 & 12.9 & 1.2 \\
2007 & 2,869 & 1,900 & 14.2 & 1.3 \\
2008 & 2,909 & 1,798 & 15.7 & 1.4 \\
2009 & 2,853 & 1,816 & 18.6 & 1.4 \\
2010 & 2,584 & 1,836 & 18.7 & 1.4 \\
2011 & 2,808 & 1,855 & 29.4 & 1.4 \\
2012 & 2,940 & 1,873 & 26.6 & 1.1 \\
\hline
\end{tabular}

From 2007 onwards categories are reclassified based on National Import Tariff Guide2010.

Coconut is grown in most parts of Sri Lanka except in the higher elevation but lease concentrated in the coconut triangle. It is cultivated in areas ranging from sea level up to elevation of about 750 meters (Wijerathna 2012).

Coconut Research Institute of Sri Lanka (CRISL) understood the urgent need of implementing of biotechnological techniques to benefit the Sri Lankan coconut industry and the promotes collaborative research with other National Institutes, Universities and Private Sector Organizations and transferring of technologies developed by CRISL to the extension staff of the Coconut Cultivation Board, coconut growers and other stakeholders through the adoptions of new methodologies.

Here author describes recent utilization of recent biotechnological approach in (a) molecular markers, diversity and genetic improvements, (b) molecular detection and diagnosis of diseases and (c) in vitro propagation in Sri Lankan condition and the future potential of biotechnology on the coconut industry.

(a) Molecular markers, diversity and genetic improvements: Application of molecular markers has risen as a productive and dominant access for 
augmenting traditional plant breeding techniques for present day breeding programs. Series of molecular markers are now accessible viz., RFLP, RAPD, SSR and AFLP are routinely being used in ecological, evolutionary, taxonomical, phylogenic and genetic studies of plant sciences.

Initially the studies were aimed at assessment of coconut genetic diversity and genetic relatedness at the DNA level using universal marker techniques such as RAPD, RFLP, AFLP (Teulat et al. 2000). Later on the need for coconut specific markers was felt and accordingly in 1999 two sets of microsatellite markers were isolated by two groups of scientists independently using the cultivars Sri Lanka Tall (Perera, 1999) and Tagnanan Tall (Rivera et al. 1999). Microsatellites, or simple sequence repeats (SSRs), are simple, tandemly repeated di- to tetranucleotide sequence motifs flanked by unique sequences. They are valuable as genetic markers because they are co-dominant, detect high levels of allelic diversity, and are easily an economically assayed by the polymerase chain reaction (PCR) (Mccouch et al. 1997). SSRs provide the most informative means for evaluating genetic diversity in coconut populations.

Gene diversity and polymorphism information content (PIC) were relatively higher in the common 'tall' coconut and Pacific tall coconut than in autogamous dwarf form of coconut. The SSR assessment unveiled the genetic lineages based on evolutionary mechanisms signifying the narrow genetic base of coconut germplasm, with most of the diversity confining to 'tall' coconut. The main genetically different coconut groups identified were 'tall', 'San Ramon and alike' and 'dwarf'. These have already been utilized in coconut improvement programs and the study emphasizes the need for enrichment of the gene pool by exotic introductions (Dasanayaka et al. 2009).

Genetic diversity of seventeen germplasm accessions and three improved cultivars was determined by RAPO analysis. Twenty Operon primers selected from 100 primers were used and these primers amplified coconut DNA generating 129 amplification products averaging 6.5 bands per primer. Among them $84(65.12 \%)$ exhibited polymorphisms averaging 4.2 polymorphic bands per primer (Dasanayaka et al. 2005).

A very high level of within population variation (99\%) accounted for native populations suggests a common history and a restricted genetic base for native Sri Lankan tall coconuts. The study based on SSRs revealed a very low level of population differentiation (Perera et al. 2001). A single large random collection from the whole target area would capture most of the variation found in the Sri Lankan tall coconut variety Typica form typica. Further the existing ex situ gene bank adequately represents the target collection area and hence further random 
collections would not be necessary. The study highlights the importance of utilizing exotic germplasm in the breeding program (Perera et al. 2001).

The dendrogram based on genetic distances depicted the genetic relatedness of the accessions by clustering into two major groups. The first comprised all dwarf forms, aurantiaca form King coconut, and San Ramon. According to the earlier classification King Coconut (aurantiaca) form is an intermediate form between tall and dwarf forms. But here King Coconut has grouped with dwarf forms. Even most of the morphological (slender trunk) and reproductive characters (self-pollinating and profuse bearing capacity) of King Coconut also place it more towards a dwarf than a typical Sri Lanka tall. Similar observations have also been reported by Perera et al. (1998a and 2000) through variations detected by amplified fragment length polymorph isms (AFLPs) and simple sequence repeats (SSRs) (Dasanayaka et al. 2005).

The genetic relatedness of the coconut in Sri Lanka was accurately explained by the RAPD assay. The coconut germplasm conserved ex-situ in the Coconut Research Institute has a narrow genetic base indicating fewer chances for substantial genetic improvement. The two accessions somewhat distant being exotic types, Brazilian Green Dwarf and San Ramon suggest the possibility of introducing exotic coconuts for gene pool enrichment (Dasanayaka et al. 2005).

AFLP revealed overall most variation was detected in the tall (Typica) rather than the intermediate (Aurantiaca) and dwarf (Nana) forms. A hierarchical analysis of molecular variance (AMOVA) was revealed that for the inbreeding dwarf and intermediate forms most variation was observed between, rather than within, forms. In contrast, the outbreeding tall forms exhibited as much variation within as between forms (Perera et al. 1998b).

Morphologically the Aurantiaca group of accessions are considered to be intermediate between the tall and dwarf accessions. Estimation of genetic relatedness based on AFLP analysis identified the Aurantiaca group as being more similar to the dwarf rather than the tall group (Perera et al. 1998b).

Microsatellite markers can be used to uniquely identify seed parents in coconut breeding program and hybrids. A microsatellite (SSR) marker based approach was used to develop an identification method for coconut varieties; Sri Lanka Tall, Sri Lanka Green Dwarf and Sri Lanka Yellow Dwarf, the key parents in the breeding programs and tall $x$ dwarf hybrids among them, using 18 coconut specific SSR primers. The validity of using yellow color petiole as a phenotypic marker for the identification of dwarf yellow was also investigated (Perera 2010). This is very important for confirming the identity of varieties and their hybrids in the most likely events of mixing of seed-nut lots, mislabeling of seeds in nurseries and checking the legitimacy of hybrid seedlings. 
(b) Molecular detection and diagnosis of diseases: Today DNA marker technologies have been revolutionized the plant patho-genomic analysis and have been extensively employed in many fields of molecular plant pathology. The most important consideration in the issue of large scale importation of coconut for industries or consumption is the possibility of inadvertent introduction of serious pathogens and quarantine pests of coconut. Molecular methods are useful for both to monitor anthropogenic viral, bacterial, and protozoan entero-pathogens, and to track pathogen specific markers in a complex environment in order to reveal sources of these pathogens (Graczyk and Conn. 2008). Molecular detection and diseases diagnosis kits have developed as resourceful tools for quickly and sometimes cheaply assessing diverse aspects of plant pathogen genomes.

Molecular pathogen diagnosis technology has been used to detect Phytoplasma; the causative agent of Weligama Coconut Leaf Wilt disease and causal agents in some unknown disease conditions Coconut Cadang Cadang Viroid disease ( CCCVd ).

In late 1990, the rapid death of coconut palms was reported from an estate owned by the Coconut Research Institute of Sri Lanka (CRISL) and a private holding in the north-western province. Usually affects 15 - 35 year old palms and characteristic symptoms of the disease are; trunk tapering, reduced crown size, cessation of nut production and death of crown in $\sim 3-10$ years. The tapering disease condition is widespread in coconut plantation in Sri Lanka and it is a serious concern of the growers and is a serious problem in coconut plantation in Sri Lanka contributing to significant yield loss (Wijerathna 2012).

Samples that were collected from premature decline coconut palm in 1990 were probed by Northern blot with 32P CCCVd at University of Adelaide, Waite by D Hanold and J. W. Randles lab. Three samples were bound the probe at high stringency and 2D gel electrophoresis indicated presence of CCCVd related viroid sequence in coconut in Sri Lanka (Wijerathna 2012).

A ribonuclease protection assay (RPA) has been developed for detecting Coconut cadang-cadang viroid $(\mathrm{CCCVd})$ sequences. An RNA probe complementary to full-length CCCVd246 was used, terminating at nucleotide 65 in the upper conserved region, and linked to a non-viroid $5^{\prime}$ sequence, which acted as an internal control for ribonuclease activity. Of four coconut palms in Sri Lanka shown by dotblot assay to contain CCCVd-related RNA, one was shown by RPA to be positive for the CCCVd246 sequence (Vadamalai et al. 2009).

Preliminary studies have been done by using many different DNA based and PCR based molecular disease diagnosis techniques have indicated the presence of viroid-like molecules in the Sri Lanka coconut population. It indicates that 
these molecules are present in high frequency in the coconut tapering disease palms. These molecules when checked against the NCBI sequence data base found closely related to Coconut cadang-cadang viroid (CCCVd) which is the causal agent of the coconut cadang cadang disease in the Philippines. Coconut cadang cadang disease in the Philippines is a lethal disease condition in coconut and other Palme species in the Philippines and the diseased coconut palms of those resemble more or less to the Tapering diseased palms in Sri Lanka (Wijerathna 2012)

Weligama Leaf Wilt Disease (WCLWD) is the most recent disease of the coconut palm reported in Sri Lanka. WCLWD was first reported in 2004 in Weligama area in Southern Sri Lanka, and molecular disease diagnosis initiated in 2007 with CCCVD specific primers and universal phytoplasma specific primers.

Molecular pathogen diagnostics methods have revealed intra-cellular pathogen "phytoplasma" to be the causal agent of WCLWD. Intra-cellular pathogen phytoplasma are obligatory parasites of the plants. The danger of phytoplasma associated diseases is their incurable nature. Sri Lanka was considered to be free of phytoplasma associated diseases in coconut until the diagnosis of WCLWD. However, several lethal diseases of coconut such as lethal yellowing in the Africa and America and Kalimanthan wilt in Indonesia and slow decaying diseases such as Kerala wilt in India have been reported to be caused by phytoplasma (Wijerathna 2012).

DNA extracted from midribs of spear leaves was subjected to nested PCR with phytoplasma universal primers R16F2n/R16R2 and R16mF2/R16R2 nested with fU5/rU3; P1/P7 nested with Chrfor/rU3; and directs PCR with Pc399/P1694. PCR products of expected sizes were obtained from diseased but not from healthy palms from a disease-free area. The sequences generated from the PCR products were submitted to similarity search (BlastN) in the NCBI database which confirmed that a phytoplasma belonging to the 16SrXI "Candidatus Phytoplasma oryzae" group is associated with WCLWD. The phytoplasma was found to be highly similar but not identical to Sugarcane white leaf phytoplasma (99\%), Sugarcane grassy shoot phytoplasma (99\%) and Kerala wilt phytoplasma (99\%) (Perera et al. 2012).

These new techniques are effective management tools to be used in parallel with knowledge of the crop, understanding the biology of the pathogen and the ecology of the disease. Thus, these tools can be excellent tool to determine the point in time at which control measures should be implemented. In addition, such diagnostic assays are essential tools for programs devised to produce intercellular pathogen free plant propagation materials (Wijerathna 2012). 
(c) in vitro propagation: Coconut being an important palm in the tropics needs improvement in coconut producing countries like Sri Lanka. Tissue culture techniques are now used to speed up crop improvement by cloning of elite planting material. Since the 1970's in vitro cloning of coconut has been attempted using various tissues such as root, shoot tip, immature inflorescence, tender leaf, immature zygotic embryo and plumule. Unfertilized ovary is promising explants for micropropergation of coconut (V.R.M. Vidhanaarachchi, pers. comm.).

Tissue culture research program is focused on the development a reliable clonal propagation method using unfertilized ovary explants, double haploid production through anther culture, propagation of 'Dikiri pol' (Makapuno - type of coconut)via mature zygotic embryo rescue technique (Fig. 1.) and Molecular studies on coconut embryogenesis (V.R.M. Vidhanaarachchi, pers. comm.).

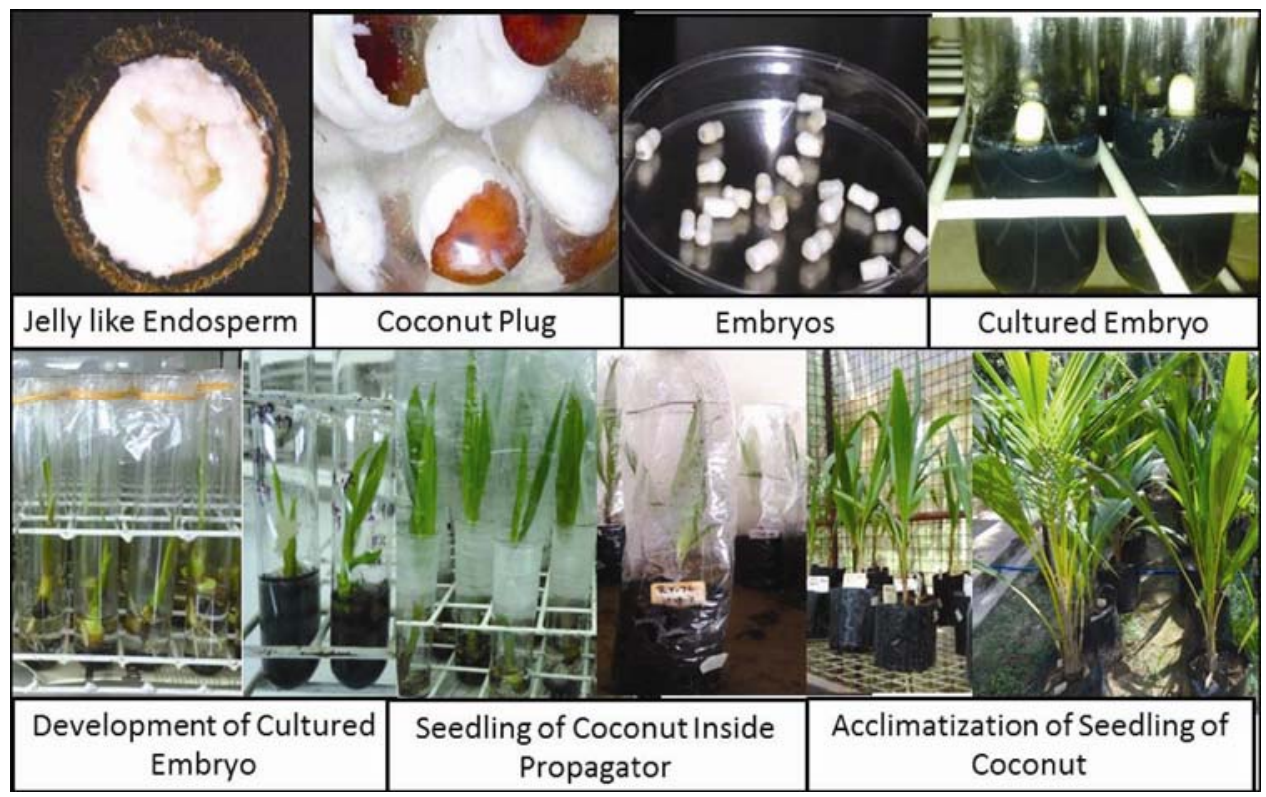

Fig. 1. Propagation of Dikiri coconut using embryo culture technique and hardening.

Much emphasis was placed on culture of unfertilized ovaries, the most promising explant for clonal propagation. Due to the high demand for planting material of improved varieties, ovary cultures were initiated using explants collected from 3 improved varieties of coconut, namely CRIC 65, CRISL 98 and Kapruwana. In addition, ovaries of two dwarf varieties (Dwarf Green and Dwarf Yellow) were also cultured (V.R.M. Vidhanaarachchi , pers. comm.).

Production of Double haploid plants through tissue culture technology has a great potential in producing homozygous lines for hybrid plant production. The 
haploids are induced by triggering the normal developmental process of the gametes in to the sporophytic pathway. For the first time, coconut haploid plants were produced consistently from the research carried out at the CRI SL (Perera et al. 2010). Doubling the chromosome number of haploids offers a method for the rapid production of homozygous lines that in turn can be used for producing inbred lines for hybrid production.

Furthermore, haploid callus and cell lines are useful material for the in vitro mutagenesis, genetic transformation and somatic hybridization. Anthers, microspores and ovules can be used as explants for the production of dihaploid plants. Early attempts made by various research groups for in vitro production of dihaploids were not successful. Initial studies undertaken at the tissue culture division of CRISL have resulted in identification of the most suitable time of inflorescence collection for correct developmental stage of pollen for dihaploid production (M.M.W.K.B Manchanayake, pers. comm.).

Unfertilized ovaries isolated from immature female flowers of coconut were tested as a source of explants for callogenesis and somatic embryogenesis. The correct developmental stage of ovary explants and suitable in vitro culture conditions for consistent callus production were identified. Embryogenic calli were sub-cultured into somatic embryogenesis induction medium containing 5 microM abscisic acid, followed by plant regeneration medium (with 5 microM 6benzyl aminopurine). Many of the somatic embryos formed were complete with shoot and root poles and upon germination they gave rise to normal shoots (Fig. 2.). However, some abnormal developments were also observed. Flow cytometric analysis revealed that all the calli tested were diploid. Through histological studies, it was possible to study the sequence of the events that take place during somatic embryogenesis including orientation, polarization and elongation of the embryos (Perera et al. 2007).

Consistent callogenesis was obtained by culturing unfertilised ovaries at - 4 stage in CRI 72 medium containing $100 \mu \mathrm{M} 2,4-\mathrm{D}$ and $0.1 \%$ activated charcoal. Callusing was improved by application of $9 \mu \mathrm{M}$ thidiazuron (TDZ). Embryogenic calli were subcultured onto somatic embryogenesis induction medium containing $66 \mu \mathrm{M}$ 2,4-D. Stunted growth was observed in the somatic embryos after subculture onto CRI 72 medium containing ABA. Maturation of somatic embryos could be achieved in $Y_{3}$ medium without growth regulators. Conversion of somatic embryos was induced by adding $\mathrm{GA}_{3}$ to conversion medium containing $5 \mu \mathrm{M}$ 6-benzyladenine (BA) while 2-isopentyl adenine (2iP) increased the frequency of plant regeneration. A total of 83 plantlets were produced from 32 cultured ovaries (Perera et al. 2009a). 


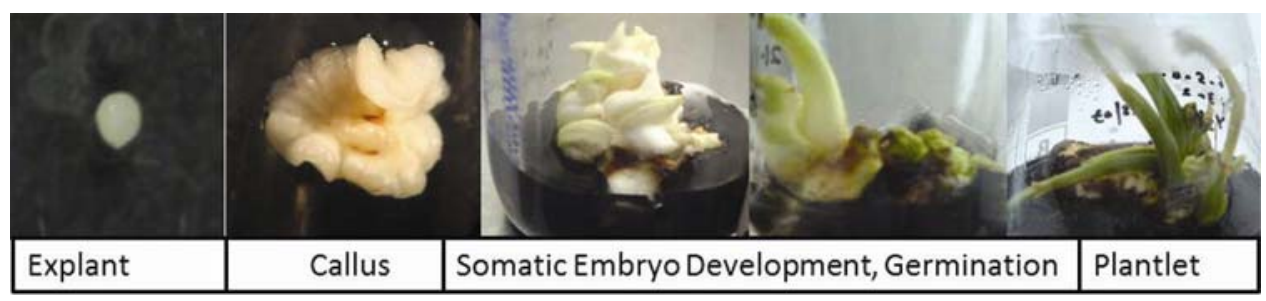

Fig. 2. In vitro plant regeneration through somatic embryogenesis.

Tall coconut palm is an allogamous and variable species, is highly heterozygous which a major constraint in conventional breeding (Perera et al. $2009 b)$. For the first time, that there is a feasibility of developing homozygous lines in coconut via anther culture. Growth regulators are critical for controlling the androgenic response. (Perera et al. 2008a, b).

Simple sequence repeat (SSR) marker analysis was used to identify the homozygous diploid individuals among dihaploid plantlets obtained via anther culture. Using a diagnostic SSR marker (CNZ43), all the diploid plantlets tested were identified as being derived from microspores (i.e. were homozygous) and were thus candidates for use in coconut breeding programs (Perera et al. 2008 b).

The importance of developing a clonal propagation method for coconut is now well accepted. The difficulties encountered in realizing it have also been identified. At present, the unfertilized ovary appears to be the most suitable explant due to a relatively high regeneration potential and application in clonal propagation of adult elite palms. Effort $\mathrm{s}$ to standardize callusing medium and multiplication of embryogenic callus has given encouraging results (Fernando 2008).

Finally, Biotechnology can be used to improve coconut in several ways. By improving our knowledge of coconut diversity, molecular methods could help breeders effectively choose varieties to be used in a breeding program to maximize heterosis and the chances of incorporating useful genes. It could also be used to identify markers for quantitative trait loci (QTLs), i.e. individual genes that contribute significantly to the diversity of a quantitative trait. Finally, if a large number of inexpensive markers is available, association mapping can be performed in natural or breeding populations without the need for a precise knowledge of the pedigrees (Batugal et al. 2009)

Crop improvement programs in coconut led to Germplasm management (Collection of germplasm, conservation and cataloguing of germplasm) development of hybrids, DNA fingerprinting and MAS and Testing individual palms/or combining ability are the developments in biotechnology of coconut. 


\section{Conclusion}

This study also provided insights into a long term strategy and plan are needed to boost coconut production. There have been several studies that have pointed out the needed new directions to resuscitate the coconut industry and research in the Coconut Research Institute. To foster the industry for the demand of production, application and utilization of biotechnology on the coconut industry is necessary by weighing the advantages and pointing out areas where work should be directed to stimulate further research. These observations have important implications for the maintenance and collection of coconut germplasm for the future breeding programs. Immediate actions from the government and private sector should be implemented by shifting to investigate how the use of recently developed biotechnological techniques can benefit the long term coconut industry.

\section{Acknowledgement}

The author is thankful to Dr. A. A. F. L. K. Perera, Dr. (Ms.) V. R. M. Vidhanaarachchi, Dr. (Ms) S. C. N. Perera Mr. K Meegahakumbura and Mrs. W. B. S Fernando of the Genetics and Plant Breeding Division, Coconut Research Institute Sri Lanka, Dr. (Ms.) S. N. T. De.Silva, Dr. (Ms.) A. N. K. Perera and Ms. M. M. W. K. B. Manchanayake of Department of Biotechnology of Wayamba University of Sri Lanka are acknowledged for their corporation for the study and guidance.

\section{References}

Anon. (2014) Nutrition data know what you eat: an annotated database. Available at: $<$ http://nutritiondata.self.com /facts/nut-and-seed-products/3106/2>. Accessed on: 14 May 2014.

Batugal P, Bourdeix R and Baudouin L (2009) Coconut Breeding. In: Jain S. M.; Priyadarshan P. M. (Ed.). Breeding Plantation Tree Crops: Tropical Species. Springer New York. pp.327-375.

Central Bank. External Sector Performance - February (2014) [Press release]: an annotated database. Available at: <http://www.cbsl.gov.lk/pics_n_docs/02_prs/_docs/press/ press_20140505e.doc>. Accessed on: 14 May 2014.

Collard BCY, Jahufer MZZ, Brouwer JB and Pang ECK ( 2005) An introduction to markers. quantitative trait loci (QTL) mapping and marker assisted selection for crop improvement: The basic concepts. Euphytica 142: 169-196.

Dasanayaka PN, Everard JMDT, Karunanayaka EH and Nandadasa HG (2005) Genetic diversity of coconut (Cocos nucifera L.) in Sri Lanka revealed by randomly amplified polymorphic DNA (RAPD) markers. Vidyodaya J. Sci. 12: 107-117. 
Application of biotechnology in coconut

Dasanayaka PN, Everard JMDT, Karunanayaka EH and Nandadasa HG (2009) Analysis of coconut (Cocos nucifera L.) diversity using microsatellite markers with emphasis on management and utilisation of genetic resources. Journal of the National Science Foundation of Sri Lanka. 37 (2): 99-109.

Fernando SC (2008) Clonal Propagation of Coconut: Prospects and Limitations. In: Proc. of Second Symposium on Plantation Crop Research. October, 2008. pp. 322- 326.

Graczyk TK and Conn DB (2008) Molecular Markers and Sentinel Organisms for Environmental Monitoring. Parasite 15: 458-462.

Liyanage DV (1958) Varieties and forms of coconut palms grown in Ceylon. Ceylon Coconut Quarterly 9: 1-10.

McCouch SR, Chen X, Panaud O, Temnykh S, Xu Y, Cho YG, Huang N, Ishii T and Blair M (1997) Microsatellite marker development. mapping and applications in rice genetics and breeding. Plant Molecular Biology 35: 89-99.

Menon KPV and Pandalai KM (1958) The coconut. A monograph. Indian Central Coconut Committee. pp. 86-102.

Perera L, Russel JR, Provan J and Powell W (1998a) Evaluating genetic relationships between indigenous coconut (Cocos nucifera L.) accessions from Sri Lanka by means of AFLP profiling. Theoretical and Applied Genetics 96: 545-550.

Perera L, Russel JR, Provan J, McNicol JW and Powell W (1998b) Evaluating genetic relationships between indigenous coconut (Cocos nucifera L.) accessions from Sri Lanka by means of AFLP profiling. Theoretical and Applied Genetics 96: 545-550.

Perera L, Russel JR, Provan J and Powell W (1999) Identification and characterization of microsatellite loci in coconut (Cocos nucifera L.) and the analysis of coconut populations in Sri Lanka. Molecular Ecology 8: 344-346.

Perera L, Russel JR, Provan J and Powell W (2000) Use of micro satellite DNA markers to investigate the level of genetic diversity and population genetic structure of coconut (Cocos nucifera L.). Genome 43: 15-21.

Perera L, Russel JR, Provan J and Powell W (2001) Levels and distribution of genetic diversity of coconut (Cocos nucifera L. var. Typica form typica) from Sri Lanka assessed by microsatellite markers. Euphytica 122: 381-389.

Perera PIP, Hocher V, Verdeil J, Doulbeau S, Yakandawala DMD and Weerakoon LK (2007) Unfertilized ovary: A novel explant for coconut (Cocos nucifera L.) somatic embryogenesis. Plant Cell Report 26:1-8.

Perera PIP, Hocher V, Verdeil J, Bandupriya HDD, Doulbeau S, Yakandawala DMD and Weerakoon LK (2008a) Androgenic potential in coconut(Cocos nucifera L.). Plant Cell Tiss. Org. Cult. 92(3): 293-302.

Perera PIP, Perera L, Hocher V, Verdeil J, Doulbeau S, Yakandawala DMD and Weerakoon LK (2008b) Use of SSR markers to determine the anther-derived homozygous lines in coconut. Plant Cell Report 27(11): 1697-703.

Perera PIP, Vidhanaarachchi VRM, Gunathilake TR, Yakandawala DMD, Hocher V, Verdeil JL and Weerakoon LK (2009a) Effect of plant growth regulators on ovary culture of coconut (Cocos nucifera L.). Plant Cell Tiss. Org. Cult. 99 (1): 73-81. 
Perera PIP, Yakandawala DMD, Hocher V, Verdeil JL and Weerakoon LK (2009b) Effect of growth regulators on microspore embryogenesis in coconut anthers. Plant Cell Tiss. Org. Cult. 96: 171-180.

Perera L ( 2010) Hybrid Testing and Variety Identification of Coconut (Cocos nucifera L.) in Sri Lanka Using Microsatellite Markers. Cord. 26(1): 39.

Perera PIP, Yakandawala DMD, Verdeil JL, Hocher V and Weerakoon LK (2010) Morphological aspects of coconut anther culture derived structures. J. Nat. Sci. Found. Sri Lanka. 38(1):69-74.

Perera L, Meegahakumbura MK, Wijesekara, HRT, Fernando WBS and Dickinson MJ (2012) A Phytoplasma is Associated with The Weligama Coconut Leaf Wilt Disease in Sri Lanka. Journal of Plant Pathology. 94(1): 205-209.

Rivera R, Edwards KJ, Barker JHA, Arnold GM, Ayad G, Hodgkin T and Karp A (1999) Isolation and characterization of polymorphic micrsatellites in Cocos nucifera $\mathrm{L}$. Genome 42: 668-675.

Teulat B, Aldam, C, Trehin R, Lebrun P, Barker JHA, Arnold GM, Karp A, Baudouin L and Rognon F (2000) An analysis of genetic diversity in coconut (Cocos nucifera) populations from across the geographic range using sequence-tagged microsatellites (SSRs) and AFLPs. Theoritical and Applied Genetics 100: 764-771.

Vadamalai G, Perera, L, Hanold D, Rezaian MA and Randles JW (2009) Detection of Coconut cadang-cadang viroid sequences in oil and coconut palm by ribonuclease protection assay. Annals of Applied Biology 154(1): 117-125.

Wijerathna YMAM (2012) Application of Biotechnology in Intra Cellular Pathogen Diagnostic of Coconut (Cocos nucifera L.) in Sri Lanka. Report on In-plant Training Program. Wayamba University of Sri Lanka pp 81. 